\title{
ERNICA Consensus Conference on the Management of Patients with Long-Gap Esophageal Atresia: Perioperative, Surgical, and Long-Term Management
}

\author{
Carmen Dingemann ${ }^{1}$ Simon Eaton ${ }^{2}$ Gunnar Aksnes ${ }^{3}$ Pietro Bagolan ${ }^{4}$ Kate M. Cross ${ }^{5}$ \\ Paolo De Coppi ${ }^{2,5}$ JoAnne Fruithof ${ }^{6}$ Piergiorgio Gamba ${ }^{7} \quad$ Imeke Goldschmidt ${ }^{8} \quad$ Frederic Gottrand ${ }^{90}$ \\ Sabine Pirr ${ }^{10}$ Lars Rasmussen $^{11}$ Rony Sfeir ${ }^{12}$ Graham Slater $^{13}$ Janne Suominen ${ }^{14}$ \\ Jan F. Svensson ${ }^{15}$ Joergen M. Thorup ${ }^{16}$ Stefaan H. A. J. Tytgat ${ }^{17}$ David C van der Zee ${ }^{17}$ \\ Lucas Wessel $^{18}$ Anke Widenmann-Grolig ${ }^{19} \quad$ René Wijnen $^{20}$ Wilhelm Zetterquist $^{21}$ Benno M. Ure ${ }^{1}$
}

${ }^{1}$ Department of Pediatric Surgery, Hannover Medical School, Hannover, Germany

${ }^{2}$ NIHR Biomedical Research Centre at UCLH, Developmental Biology and Cancer Programme, UCL Great Ormond Street Institute of Child Health, London, United Kingdom

${ }^{3}$ Department of Pediatric Surgery, Oslo University Hospital, Oslo, Norway

${ }^{4}$ Department of Medical and Surgical Neonatology, Research Institute, Bambino Gesù Children's Hospital, Rome, Italy

${ }^{5}$ Department of Neonatal and Paediatric Surgery, Great Ormond Street Hospital for Children, London, United Kingdom

6 Esophageal Atresia and Tracheo-Esophageal Fistula Support Federation and VOKS, Lichtenvoorde, The Netherlands

${ }^{7}$ Department of Pediatric Surgery, University of Padua, Padua, Italy

8 Department of Pediatric Gastroenterology and Hepatology, Hannover Medical School, Hannover, Germany

${ }^{9}$ Department of Pediatric Gastroenterology, Hepatology and Nutrition, Reference Center for Rare Esophageal Diseases, CHU Lille, University of Lille, Lille, France

${ }^{10}$ Department of Pediatric Pulmonology, Allergology and Neonatology, Hannover Medical School, Hannover, Germany

${ }^{11}$ Department of Pediatric Surgery, Odense University Hospital, Odense, Denmark

${ }^{12}$ Department of Pediatric Surgery, Reference Center for Rare Esophageal Diseases, CHU Lille, University of Lille, Lille, France
Address for correspondence Carmen Dingemann, MD, Department of Pediatric Surgery, Hannover Medical School, Carl-Neuberg-Str. 1, Hannover 30625, Lower Saxony, Germany

(e-mail: dingemann.carmen@mh-hannover.de; carmendingemann@gmail.com).

${ }^{13}$ Esophageal Atresia and Tracheo-Esophageal Fistula Support Federation and TOFS, Nottingham, United Kingdom

${ }^{14}$ Department of Pediatric Surgery, University of Helsinki, Helsinki, Finland

${ }^{15}$ Department of Pediatric Surgery, Karolinska University Hospital, Stockholm, Sweden

16 Department of Pediatric Surgery, Copenhagen University Hospital, Rigshospitalet, Copenhagen, Denmark

${ }^{17}$ Department of Pediatric Surgery, Wilhelmina Children's Hospital, University Medical Center Utrecht, Utrecht, The Netherlands

${ }^{18}$ Department of Pediatirc Surgery, University Medical Center Mannheim, Medical Faculty Mannheim, University of Heidelberg, Mannheim, Germany

${ }^{19}$ Esophageal Atresia and Tracheo-Esophageal Fistula Support Federation and KEKS, Stuttgart, Germany

${ }^{20}$ Department of Pediatric Surgery, Erasmus MC, Rotterdam, The Netherlands

${ }^{21}$ Department of Woman and Child Health, Karolinska University Hospital, Stockholm, Sweden Eur J Pediatr Surg 2021;31:214-225.
Abstract
Keywords
- long-gap esophageal atresia
- pediatric surgery
- management
- follow-up
- consensus conference

Introduction Evidence supporting best practice for long-gap esophageal atresia is limited. The European Reference Network for Rare Inherited Congenital Anomalies (ERNICA) organized a consensus conference on the management of patients with longgap esophageal atresia based on expert opinion referring to the latest literature aiming to provide clear and uniform statements in this respect.

Materials and Methods Twenty-four ERNICA representatives from nine European countries participated. The conference was prepared by item generation, item prioritization by online survey, formulation of a final list containing items on perioperative, surgical, and long-term management, and literature review. The 2-day conference was held in Berlin in November 2019. Anonymous voting was conducted via an received

April 9, 2020

accepted

May 25, 2020

published online

July 15,2020 (c) 2020. Thieme. All rights reserved.

Georg Thieme Verlag KG,

Rüdigerstraße 14,

70469 Stuttgart, Germany
DOI https://doi.org/

10.1055/s-0040-1713932.

ISSN 0939-7248. 
internet-based system using a 1 to 9 scale. Consensus was defined as $\geq 75 \%$ of those voting scoring 6 to 9 .

Results Ninety-seven items were generated. Complete consensus $(100 \%)$ was achieved on 56 items (58\%), e.g., avoidance of a cervical esophagostomy, promotion of sham feeding, details of delayed anastomosis, thoracoscopic pouch mobilization and placement of traction sutures as novel technique, replacement techniques, and followup. Consensus $\geq 75 \%$ was achieved on 90 items (93\%), e.g., definition of long gap, routine pyloroplasty in gastric transposition, and avoidance of preoperative bougienage to enable delayed anastomosis. Nineteen items (20\%), e.g., methods of gap measurement were discussed controversially (range 1-9).

Conclusion This is the first consensus conference on the perioperative, surgical, and long-term management of patients with long-gap esophageal atresia. Substantial statements regarding esophageal reconstruction or replacement and follow-up were formulated which may contribute to improve patient care.

\section{Introduction}

In 1 out of 10 patients with esophageal atresia, primary anastomosis of the two esophageal ends is not feasible ${ }^{1,2}$ which poses an additional major challenge to restore continuity. ${ }^{1-7}$ The rarity of the condition, the variability in case definition, multiple approaches to management and follow-up, and the heterogeneity of the reported outcomes contribute to this challenge. ${ }^{3}$ In addition, evidence supporting best practice for long-gap esophageal atresia is limited, mostly consisting of single-center retrospective reviews with low numbers of patients, and low quality of data to date. ${ }^{1-5}$ As a result, there is a variety of coexisting protocols on the perioperative, surgical, and long-term management of patients with long-gap esophageal atresia based on opinion rather than on evidence. This was confirmed in a recent survey of pediatric surgeons demonstrating the variability in opinion, in terms of both case definition and preferred operative approaches. ${ }^{8}$

The European Reference Network for Rare Inherited Congenital Anomalies (ERNICA) has been established in response to the European Commission's call for the setup of European Reference Networks for rare diseases in $2017 .{ }^{9}$ The network seeks to deliver high standards of care, to build capacity where there is lack of knowledge and infrastructure, and to promote optimal patient care for rare inherited and congenital digestive tract-related disorders from pediatric age to adulthood. ${ }^{10-13}$

ERNICA organized a first consensus conference on the pre, peri-, and postoperative management as well as on the follow-up of patients with esophageal atresia with tracheoesophageal fistula in October 2018. ${ }^{14,15}$ ERNICA has now conducted a second consensus conference which focused on the management of patients with long-gap esophageal atresia based on expert opinions referring to the latest literature. The aim of this conference was to develop clear and uniform statements in this respect.

\section{Materials and Methods}

The general methodological approach has been recently published when presenting the results of the first ERNICA consensus conference. ${ }^{14,15}$ It consisted of two parts: (1) diagnostics, preoperative, operative, and postoperative management $^{14}$ and (2) follow-up and framework. ${ }^{15}$

The conference dealt exclusively with the management of patients with long-gap esophageal atresia, and took place in Berlin on November 13-14, 2019. In total, 24 ERNICA representatives from nine European countries participated: 16 pediatric surgeons, 2 pediatric gastroenterologists, 1 neonatologist, 1 pediatric pulmonologist, 3 representatives of patient support groups acting under the umbrella of the Federation of Esophageal Atresia and Tracheo-Esophageal Fistula Support Groups (EAT). ${ }^{16}$ One nonsurgeon methodologist (S.E.) took part in all steps of the preparation and the conference itself.

With regard to literature selection, publications with the highest grade of evidence according to the Centre for Evidence-Based Medicine (CEBM) classification were suggested to be preferred ${ }^{17}$ as previously reported. ${ }^{14,15}$ Literature was distributed and made available to all participants via a Dropbox (Dropbox Inc., San Francisco, California, United States, 2007) link prior to the conference.

The preparation and implementation of the conference included the following steps ${ }^{14,15}$ : (1) generation of a list of items; (2) prioritization of the items using the online REDCap electronic data capture tools ${ }^{18}$; (3) literature-based discussion of all items on the perioperative, surgical, and long-term management of patients with long-gap esophageal atresia during the conference, formulation of statements; (4) anonymous voting via the internet-based system VoxVote (VoxVote, Breda, The Netherlands) using a 1 to 9 scale. $^{19}$

It was suggested to the participants that they abstained from voting on any individual item when they felt that they had no expertise or an opinion on that item. Therefore, participants were allowed to vote online "no relevant expertise on this statement." As a result, the number of scoring participants varied for individual statements. Consensus was defined as $\geq 75 \%$ of those voting scored $6,7,8$, or 9 , excluding those who declared no relevant expertise on that statement. ${ }^{14,15}$

The wordings of the statements on items were updated during the discussion by the participants of the conference 
and prepared for voting by the nonsurgical methodologist (S. E.) who did not himself vote.

The final scores and the consensus results were shown to all participants after all votes were obtained, but individual scores remained anonymous. Details of the discussions, in particular the controversial aspects, were documented throughout the conference by C.D.

\section{Results and Consensus Statements}

\section{Item Generation and Prioritization}

The systematic literature search and the discussion of the members of the ERNICA Workstream Congenital Malformations and Diseases of the Esophagus during the third ERNICA Annual Meeting in Padua, Italy on April 11-12, 2019, resulted in a total of 87 items.

After the online prioritization phase, two items were excluded. Following the participants' suggestions, one new item was added. Consequently, the list included 86 items prior to the conference, for which literature was obtained and circulated.

As a result of the presentations by the domain leaders and active discussion during the conference, 14 items were excluded, and 25 were added as some items were split into several separate questions.

Finally, 97 items were reworded and confirmed for voting. This included 8 items in the domain Diagnostics, 4 items in the domain Definitions, 43 items in the domain Esophageal Reconstruction, 9 items in the domain Esophageal Replacement, 6 items in the domain Postoperative Management, 23 items in the domain Follow-up, and 4 items in the domain Framework (-Tables 1-7).

Several items of the domain Follow-up have been adopted from the guidelines released by the European Society for Pediat- ric Gastroenterology Hepatology and Nutrition (ESPGHAN) and the North American Society for Pediatric Gastroenterology, Hepatology and Nutrition ${ }^{20}$ (NASPGHAN) and were discussed from a surgical perspective. Some items had already been discussed in a different context during the first ERNICA consensus conference on the management of patients with esophageal atresia and tracheoesophageal fistula. Therefore, the wording might be the same or modified to some extent, but was considered essential to be rediscussed to determine whether the statement was also relevant to the group of patients with long-gap esophageal atresia.

\section{Consensus}

Detailed results on the consensus among participants of the conference are summarized in -Tables 1 to 7 . For 19 items (20\%), the results ranged from 1 to 9 reflecting controversial opinions in these cases. In six of these (32\%), no consensus was reached.

-Table 8 depicts the general distribution of voting results.

There was a deviation from the established voting process using the 1 to 9 scale for one statement voting on the preferred option for esophageal replacement. In this case, participants were asked to vote on only one single option. Nine (39\%) participants preferred gastric transposition, 4 (17\%) participants preferred jejunal interposition, and 3 (13\%) participants preferred colonic interposition for esophageal replacement ( - Fig. 1). For this vote, seven (30\%) participants abstained from voting.

\section{Controversial Items Discussed without Voting}

Several items were discussed controversially, and the participants agreed verbally that more data from future research should be available before a meaningful question and vote

Table 1 Diagnostics

\begin{tabular}{|c|c|c|c|c|c|}
\hline & Statement & Consensus & $\%$ & Votes & $\begin{array}{l}\text { Median } \\
\text { (range) }\end{array}$ \\
\hline $1^{\mathrm{a}}$ & $\begin{array}{l}\text { A nasogastric tube } 10 \mathrm{Fr} \text { or larger (modified for preterm infants) } \\
\text { should be routinely inserted as a diagnostic procedure in cases with } \\
\text { suspected esophageal atresia }\end{array}$ & + & 100 & $21 / 21$ & $9(8-9)$ \\
\hline $2^{\mathrm{a}}$ & A thoracoabdominal X-ray should be routinely performed & + & 100 & $21 / 21$ & $9(9-9)$ \\
\hline $3^{\mathrm{b}}$ & $\begin{array}{l}\text { An ultrasound of the abdomen (including kidney/urinary tract) } \\
\text { should be routinely performed within the first week of life }\end{array}$ & + & 100 & $20 / 20$ & $9(7-9)$ \\
\hline $4^{\mathrm{a}}$ & $\begin{array}{l}\text { Echocardiography should be routinely performed, especially to } \\
\text { exclude a right descending aorta }\end{array}$ & + & 100 & $21 / 21$ & $9(9-9)$ \\
\hline $5^{a}$ & $\begin{array}{l}\text { A contrast study of a potential upper esophageal pouch should be } \\
\text { routinely performed as a preoperative diagnostic procedure }\end{array}$ & - & 16.7 & $3 / 18$ & $2(1-9)$ \\
\hline 6 & $\begin{array}{l}\text { Gap measurement by bougies via the upper and lower } \\
\text { bougies/gastroscope via the lower pouch is a viable option }\end{array}$ & + & 94.7 & $18 / 19$ & $9[5-9]$ \\
\hline 7 & $\begin{array}{l}\text { Gap measurement by contrast study (upper and lower pouches) is a } \\
\text { viable option }\end{array}$ & - & 40 & $8 / 20$ & $3(1-9)$ \\
\hline 8 & $\begin{array}{l}\text { A bougie in the upper pouch at the time of tracheoscopy for distal } \\
\text { fistula is viable option for gap measurement }\end{array}$ & + & 83.3 & $15 / 18$ & $8(2-9)$ \\
\hline
\end{tabular}

Abbreviation: ERNICA, European Reference Network for Rare Inherited Congenital Anomalies.

${ }^{\mathrm{a}}$ This item has already been discussed during the first ERNICA consensus conference on the management of patient with esophageal atresia with tracheoesophageal fistula.

${ }^{b}$ This item has already been discussed during the first ERNICA consensus conference on the management of patient with esophageal atresia with tracheoesophageal fistula, but in another context. 
Table 2 Definitions

\begin{tabular}{|c|c|c|c|c|c|}
\hline & Statement & Consensus & $\%$ & Votes & $\begin{array}{l}\text { Median } \\
\text { (range) }\end{array}$ \\
\hline 1 & $\begin{array}{l}\text { Any esophageal atresia without air in the abdomen should be assumed to be a long } \\
\text { gap }\end{array}$ & + & 100 & $22 / 22$ & $9(7-9)$ \\
\hline 2 & $\begin{array}{l}\text { Only patients with esophageal atresia Gross types A and B should be considered as } \\
\text { long gap }\end{array}$ & - & 42.9 & $9 / 21$ & $5(1-9)$ \\
\hline 3 & $\begin{array}{l}\text { Patients with a distal tracheoesophageal fistula at the carina or below should be } \\
\text { considered as long gap }\end{array}$ & - & 54.5 & $12 / 22$ & $6.5(1-9)$ \\
\hline 4 & $\begin{array}{l}\text { Any esophageal atresia with a gap of three vertebral bodies or more should be } \\
\text { considered as long-gap }\end{array}$ & + & 76.2 & $16 / 21$ & $8(1-9)$ \\
\hline
\end{tabular}

Table 3 Esophageal reconstruction

\begin{tabular}{|c|c|c|c|c|c|}
\hline & Statement & Consensus & $\%$ & Votes & $\begin{array}{l}\text { Median } \\
\text { (range) }\end{array}$ \\
\hline \multicolumn{6}{|c|}{ a. Initial management before reconstruction } \\
\hline $1^{\mathrm{a}}$ & $\begin{array}{l}\text { A replogle tube should be routinely placed into the upper esophageal pouch to } \\
\text { allow continuous low pressure suction }\end{array}$ & + & 100 & $22 / 22$ & $9(6-9)$ \\
\hline 2 & $\begin{array}{l}\text { Gastrostomy should usually be performed initially to allow enteral feeding and to } \\
\text { stimulate growing of the stomach }\end{array}$ & + & 100 & $22 / 22$ & $9(6-9)$ \\
\hline 3 & Formation of a cervical esophagostomy should be avoided & + & 100 & $21 / 21$ & $9(8-9)$ \\
\hline 4 & $\begin{array}{l}\text { Bougienage of the proximal and/or distal stump to enable delayed primary } \\
\text { anastomosis should be avoided }\end{array}$ & + & 78.9 & $15 / 19$ & $9(2-9)$ \\
\hline 5 & $\begin{array}{l}\text { Tracheobronchoscopy under spontaneous breathing should be performed in all } \\
\text { patients }\end{array}$ & + & 100 & $22 / 22$ & $9(8-9)$ \\
\hline 6 & $\begin{array}{l}\text { Tracheobronchoscopy should evaluate the presence of vocal cords, airway } \\
\text { anomalies (e.g., cleft), proximal/distal fistula location, and tracheobronchomalacia }\end{array}$ & + & 100 & $23 / 23$ & $9(9-9)$ \\
\hline 7 & $\begin{array}{l}\text { Parents should be routinely informed during counseling about all different surgical } \\
\text { options (replacement strategies, lengthening procedure, timing, minimal invasive, } \\
\text { and conventional techniques) }\end{array}$ & + & 81.8 & $18 / 22$ & $9(1-9)$ \\
\hline 8 & $\begin{array}{l}\text { Parents should be able to request a second opinion and made aware of patient } \\
\text { support organizations }\end{array}$ & + & 100 & $23 / 23$ & $9(6-9)$ \\
\hline 9 & Pain assessment and management protocols should be applied & + & 100 & $23 / 23$ & $9(7-9)$ \\
\hline 10 & Parental involvement and training are an essential integral part of care & + & 100 & $23 / 23$ & $9(8-9)$ \\
\hline 11 & $\begin{array}{l}\text { Early oral stimulation, including sensory stimulation and sham feeding, is required } \\
\text { to prevent abnormal oral feeding behavior, especially in the case of delayed } \\
\text { anastomosis }\end{array}$ & + & 100 & $23 / 23$ & $9(7-9)$ \\
\hline 12 & $\begin{array}{l}\text { Sham feeding should be performed as soon as possible, including when a Replogle } \\
\text { tube is in place }\end{array}$ & + & 100 & $23 / 23$ & $9(6-9)$ \\
\hline 13 & $\begin{array}{l}\text { Professional nutritional assessment and support are mandatory to prevent } \\
\text { undernutrition }\end{array}$ & + & 100 & $23 / 23$ & $9(6-9)$ \\
\hline \multicolumn{6}{|c|}{ b. Principle statements on esophageal reconstruction techniques } \\
\hline 14 & Preserving the native esophagus should be preferred as initial management & + & 100 & $22 / 22$ & $9(9-9)$ \\
\hline 15 & Delayed primary anastomosis should be preferred & + & 100 & $21 / 21$ & $9(6-9)$ \\
\hline 16 & Axial lengthening procedure is a viable option & + & 83.3 & $15 / 18$ & $7(3-9)$ \\
\hline 17 & $\begin{array}{l}\text { The Kimura advancement method of lengthening the upper pouch by extra- } \\
\text { thoracic resiting a spit fistula is not recommended }\end{array}$ & + & 100 & $17 / 17$ & $9(6-9)$ \\
\hline 18 & $\begin{array}{l}\text { Other esophageal lengthening techniques (flap, Livaditis circular myotomy, gastric } \\
\text { division) are not recommended }\end{array}$ & + & 88.2 & $15 / 17$ & $9(2-9)$ \\
\hline 19 & Jejunal interposition is a viable option for esophageal replacement & + & 87.5 & $14 / 16$ & $8.5(2-9)$ \\
\hline 20 & Colonic interposition is a viable option for esophageal replacement & - & 47.1 & $8 / 17$ & $5(1-9)$ \\
\hline 21 & Gastric transposition is a viable option for esophageal replacement & + & 100 & $17 / 17$ & $9(6-9)$ \\
\hline 22 & & + & 100 & $22 / 22$ & $9(6-9)$ \\
\hline
\end{tabular}


Table 3 (Continued)

\begin{tabular}{|c|c|c|c|c|c|}
\hline & Statement & Consensus & $\%$ & Votes & $\begin{array}{l}\text { Median } \\
\text { (range) }\end{array}$ \\
\hline & $\begin{array}{l}\text { Reconstructive surgery should only be performed in centers with recognized } \\
\text { expertise }\end{array}$ & & & & \\
\hline \multicolumn{6}{|c|}{ c. Timing of esophageal reconstruction } \\
\hline 23 & Gap assessment should be performed at 4-6 weeks & + & 100 & $19 / 19$ & $9(6-9)$ \\
\hline 24 & $\begin{array}{l}\text { Delayed primary anastomosis should be performed at the age of around 2-3 } \\
\text { months also depending on the gap assessment }\end{array}$ & + & 100 & $18 / 18$ & $9(7-9)$ \\
\hline 25 & $\begin{array}{l}\text { Esophageal replacement should be performed at the age of 2-3 months also } \\
\text { depending on the gap assessment }\end{array}$ & + & 82.4 & $14 / 17$ & $8(1-9)$ \\
\hline 26 & $\begin{array}{l}\text { Reconstruction at a very early age is a viable option when esophageal lengthening } \\
\text { technique is used }\end{array}$ & + & 93.8 & $15 / 16$ & $8(5-9)$ \\
\hline \multicolumn{6}{|c|}{ d. General aspects of operative management } \\
\hline $27^{\mathrm{a}}$ & Antibiotics should be routinely administered perioperatively & + & 100 & $20 / 20$ & $9(6-9)$ \\
\hline $28^{\mathrm{a}}$ & A central venous line should be placed before the operation & + & 100 & $20 / 20$ & $9(6-9)$ \\
\hline $29^{a}$ & An arterial line should be placed before the operation & + & 94.4 & $17 / 18$ & $9(1-9)$ \\
\hline \multicolumn{6}{|c|}{ e. Delayed primary anastomosis } \\
\hline $30^{\mathrm{a}}$ & $\begin{array}{l}\text { Horizontal or vertical or U-shaped (Bianchi) approaches (skin incision) are viable } \\
\text { approaches for conventional thoracotomy }\end{array}$ & + & 100 & $15 / 15$ & $9(7-9)$ \\
\hline $31^{a}$ & $\begin{array}{l}\text { Muscle-sparing approach is the recommended approach for conventional } \\
\text { thoracotomy }\end{array}$ & + & 100 & $17 / 17$ & $9(7-9)$ \\
\hline $32^{\mathrm{a}}$ & $\begin{array}{l}\text { Entry through the fourth intercostal space is the recommended approach for } \\
\text { conventional thoracotomy depending on assessment of gap length }\end{array}$ & + & 100 & $16 / 16$ & $9(7-9)$ \\
\hline $33^{a}$ & The extrapleural approach is the preferred approach for thoracotomy & + & 86.7 & $13 / 15$ & $9(1-9)$ \\
\hline $34^{a}$ & $\begin{array}{l}\text { In cases with suspected right descending aorta, a right-sided thoracic approach is } \\
\text { the first option }\end{array}$ & + & 93.8 & $15 / 16$ & $8(1-9)$ \\
\hline $35^{\mathrm{b}}$ & The azygos vein should be preserved whenever possible & + & 88.2 & $15 / 17$ & $7(4-9)$ \\
\hline $36^{\mathrm{a}}$ & $\begin{array}{l}\text { The esophageal anastomosis should be preferably performed with absorbable } \\
\text { sutures }\end{array}$ & + & 88.2 & $15 / 17$ & $9(1-9)$ \\
\hline $37^{\mathrm{a}}$ & $\begin{array}{l}\text { The esophageal anastomosis should be preferably performed with interrupted } \\
\text { sutures }\end{array}$ & + & 100 & $16 / 16$ & $9(7-9)$ \\
\hline $38^{\mathrm{a}}$ & A transanastomotic tube should be routinely inserted. & + & 94.7 & $18 / 19$ & $9(5-9)$ \\
\hline $39^{\mathrm{a}}$ & A chest drain should be routinely placed & - & 64.7 & $11 / 17$ & $7(2-9)$ \\
\hline $40^{\mathrm{a}}$ & The thoracoscopic approach is a viable option & + & 100 & $16 / 16$ & $9(6-9)$ \\
\hline $41^{\mathrm{a}}$ & $\begin{array}{l}\text { The thoracoscopic approach should be only performed if suitable expertise is } \\
\text { available }\end{array}$ & + & 95.2 & $20 / 21$ & $9(1-9)$ \\
\hline \multicolumn{6}{|c|}{ f. Lengthening techniques } \\
\hline 42 & $\begin{array}{l}\text { Thoracoscopic pouch mobilization and placement of traction sutures are a novel } \\
\text { technique that shows promise, but should only be performed in specialized centers } \\
\text { with prospective review and reporting of outcomes }\end{array}$ & + & 100 & $23 / 23$ & $9(6-9)$ \\
\hline 43 & $\begin{array}{l}\text { Open pouch mobilization and placement of traction sutures are a viable technique } \\
\text { that should only be performed in specialized centers with prospective review and } \\
\text { reporting of outcomes }\end{array}$ & + & 86.4 & $19 / 22$ & $9(2-9)$ \\
\hline
\end{tabular}

Abbreviation: ERNICA, European Reference Network for Rare Inherited Congenital Anomalies.

${ }^{\mathrm{a}}$ This item has already been discussed during the first ERNICA consensus conference on the management of patient with esophageal atresia with tracheoesophageal fistula.

${ }^{\mathrm{b}}$ This item has already been discussed during the first ERNICA consensus conference on the management of patient with esophageal atresia with tracheoesophageal fistula, but consensus could not be reached on this item.

could be conducted. The discussion included in particular the following aspects:

\section{Definitions}

The participants agreed to define long-gap esophageal atresia as "any esophageal atresia without air in the abdomen" or "any esophageal atresia with a gap of three vertebral bodies or more" as the lowest common denominator. However, there was a debate on whether only patients with esophageal atresia Gross types A and B or also patients with a distal tracheoesophageal fistula at the carina or below should be considered as long-gap esophageal atresia. The participants voted on the two 
Table 4 Esophageal replacement

\begin{tabular}{|c|c|c|c|c|c|}
\hline & Statement & Consensus & $\%$ & Votes & $\begin{array}{l}\text { Median } \\
\text { (range) }\end{array}$ \\
\hline \multicolumn{6}{|c|}{ Gastric transposition } \\
\hline 1 & $\begin{array}{l}\text { The anastomosis for gastric transposition should be routinely performed on the } \\
\text { patient's right side }\end{array}$ & + & 90.9 & $10 / 11$ & $8(5-9)$ \\
\hline 2 & Thoracotomy for gastric transposition should be avoided whenever possible & + & 91.7 & $11 / 12$ & $8.5(4-9)$ \\
\hline 3 & Partial gastric transposition with intrathoracic anastomosis should be avoided & + & 100 & $13 / 13$ & $8(6-9)$ \\
\hline 4 & A pyloroplasty (Mikulicz) should be routinely performed & + & 91.7 & $11 / 12$ & $8(1-9)$ \\
\hline 5 & Laparoscopically assisted gastric transposition is a viable option & + & 100 & $17 / 17$ & $9(6-9)$ \\
\hline 6 & $\begin{array}{l}\text { A jejunostomy should be routinely performed to allow postoperative feeding } \\
\text { unless sham feeding is well established }\end{array}$ & + & 95 & $19 / 20$ & $8(1-9)$ \\
\hline \multicolumn{6}{|c|}{ Jejunal interposition } \\
\hline 7 & A cervical esophagostomy is a contraindication for jejunal interposition & + & 100 & $12 / 12$ & $7(6-)$ \\
\hline \multicolumn{6}{|c|}{ Colonic interposition } \\
\hline 8 & The right hemicolon should be routinely used in an isoperistaltic manner & + & 100 & $10 / 10$ & $8(6-9)$ \\
\hline 9 & The preferred position is the posterior mediastinum & + & 100 & $12 / 12$ & $8.5(6-9)$ \\
\hline
\end{tabular}

Table 5 Postoperative management

\begin{tabular}{|c|c|c|c|c|c|}
\hline & Statement & Consensus & $\%$ & Votes & $\begin{array}{l}\text { Median } \\
\text { (range) }\end{array}$ \\
\hline 1 & $\begin{array}{l}\text { Postoperative ventilation and relaxation should be performed for up to } 5 \mathrm{~d} \text { in } \\
\text { anastomoses under tension }\end{array}$ & + & 100 & $17 / 17$ & $8(6-9)$ \\
\hline 2 & Routine postoperative antibiotic prophylaxis beyond $48 \mathrm{~h}$ is not recommended & + & 95 & $19 / 20$ & $9(5-9)$ \\
\hline $3^{a}$ & $\begin{array}{l}\text { A postoperative contrast study of the esophagus should be routinely performed } \\
\text { before the initiation of oral feeding }\end{array}$ & - & 40 & $8 / 20$ & $5(1-9)$ \\
\hline 4 & $\begin{array}{l}\text { Enteral feeding should be routinely initiated on the second postoperative day via a } \\
\text { gastric or jejunal route }\end{array}$ & + & 85 & $17 / 20$ & $8.5(3-9)$ \\
\hline $5^{a}$ & $\begin{array}{l}\text { A clinical checklist should be made available including items which should be } \\
\text { performed before first discharge (e.g., abdominal and renal ultrasound, resusci- } \\
\text { tation training for parents/caregivers) }\end{array}$ & + & 95.5 & $21 / 22$ & $9(5-9)$ \\
\hline 6 & Resuscitation training for parents and caregivers is mandatory before discharge & + & 91.3 & $21 / 23$ & $9(1-9)$ \\
\hline
\end{tabular}

Abbreviation: ERNICA, European Reference Network for Rare Inherited Congenital Anomalies.

${ }^{a}$ This item has already been discussed during the first ERNICA consensus conference on the management of patient with esophageal atresia with tracheoesophageal fistula.

\section{Table 6 Follow-up}

\begin{tabular}{|c|c|c|c|c|c|}
\hline & Statement & Consensus & $\%$ & Votes & $\begin{array}{l}\text { Median } \\
\text { (range) }\end{array}$ \\
\hline $1^{\mathrm{a}}$ & There should be a structured schedule for lifelong follow-up & + & 100 & $23 / 23$ & $9(8-9)$ \\
\hline $2^{\mathrm{a}}$ & $\begin{array}{l}\text { There should be an interdisciplinary follow-up program including surgeons, } \\
\text { gastroenterologists, pulmonologists, otolaryngologists, nutrition counseling and } \\
\text { others, with one specialist leading }\end{array}$ & + & 100 & $23 / 23$ & $9(8-9)$ \\
\hline $3^{a}$ & Proton pump inhibitors should be used for antacid prophylaxis & + & 90 & $18 / 20$ & $9(3-9)$ \\
\hline $4^{\mathrm{b}}$ & $\begin{array}{l}\text { Antacid medication should be routinely administered to at least until the age of } 12 \\
\text { months }\end{array}$ & + & 90.5 & $19 / 21$ & $9(2-9)$ \\
\hline $5^{a}$ & Antacid therapy should be tapered at the end of prophylaxis & + & 100 & $22 / 22$ & $9(6-9)$ \\
\hline $6^{\mathrm{a}}$ & $\begin{array}{l}\text { In patients with symptoms, anastomotic strictures should be diagnosed by } \\
\text { contrast and/or endoscopy }\end{array}$ & + & 100 & $21 / 21$ & $9(8-9)$ \\
\hline $7^{\mathrm{a}}$ & Anastomotic stricture should be managed by balloon or semirigid dilatation & + & 100 & $19 / 19$ & $9(8-9)$ \\
\hline $8^{a}$ & $\begin{array}{l}\text { The definition of recurrent anastomotic stricture is three anastomotic stricture } \\
\text { relapses requiring dilatation }\end{array}$ & + & 100 & $23 / 23$ & $9(7-9)$ \\
\hline
\end{tabular}


Table 6 (Continued)

\begin{tabular}{|c|c|c|c|c|c|}
\hline & Statement & Consensus & $\%$ & Votes & $\begin{array}{l}\text { Median } \\
\text { (range) }\end{array}$ \\
\hline $9^{b}$ & $\begin{array}{l}\text { Topical application of mitomycin C is a viable option in patients with recurrent } \\
\text { strictures }\end{array}$ & + & 77.8 & $14 / 18$ & $7.5(1-9)$ \\
\hline $10^{\mathrm{a}}$ & Intralesional steroids are a viable option in patients with recurrent strictures & + & 94.4 & $17 / 18$ & $7.5(5-9)$ \\
\hline 11 & $\begin{array}{l}\text { Stents are a viable option in patients with recurrent strictures, but should only be } \\
\text { used with caution }\end{array}$ & + & 94.7 & $18 / 19$ & $9(4-9)$ \\
\hline 12 & $\begin{array}{l}\text { Outpatient clinical and nutritional assessment should be performed every } 3 \text { month } \\
\text { during the first year after reconstruction }\end{array}$ & + & 100 & $23 / 23$ & $9(6-9)$ \\
\hline 13 & $\begin{array}{l}\text { Upper GI endoscopy and/or pH-impedance-metry should be performed } 1 \text { year } \\
\text { after reconstruction after tapering proton pump inhibitors }\end{array}$ & + & 100 & $19 / 19$ & $9(7-9)$ \\
\hline 14 & $\begin{array}{l}\text { Outpatient clinical and nutritional assessment is recommended at least } \\
\text { every second year until transition }\end{array}$ & + & 100 & $23 / 23$ & $9(7-9)$ \\
\hline $15^{\mathrm{a}}$ & $\begin{array}{l}\text { At least two additional endoscopies of the upper gastrointestinal tract should be } \\
\text { performed until transition }\end{array}$ & + & 100 & $23 / 23$ & $9(6-9)$ \\
\hline 16 & $\begin{array}{l}\text { Respiratory review by pulmonologists should be routinely performed for children } \\
\text { and adolescents according to a specific schedule }\end{array}$ & + & 100 & $23 / 23$ & $9(7-9)$ \\
\hline 17 & $\begin{array}{l}\text { Contrast study of the upper gastrointestinal tract should not be routinely used for } \\
\text { monitoring children and adolescents according to a specific schedule }\end{array}$ & + & 100 & $23 / 23$ & $9(7-9)$ \\
\hline 18 & Bronchoscopy is recommended for symptomatic children & + & 100 & $23 / 23$ & $9(6-9)$ \\
\hline $19^{a}$ & $\begin{array}{l}\text { Adult patients need surveillance as per ESPGHAN guidelines: ( } 1 \text { ) routine endoscopy } \\
\text { every } 5-10 \mathrm{y},(2) \text { endoscopy if new or worsening symptoms occur, and ( } 3 \text { ) in } \\
\text { presence of Barrett as per consensus recommendations }\end{array}$ & + & 100 & $23 / 23$ & $9(6-9)$ \\
\hline 20 & $\begin{array}{l}\text { A specific transition program for adolescents with long-gap esophageal atresia } \\
\text { should be organized }\end{array}$ & + & 100 & $23 / 23$ & $9(6-9)$ \\
\hline $21^{a}$ & $\begin{array}{l}\text { Quality of life assessment using a validated instrument should be offered during } \\
\text { follow-up in children, adolescents, and adult patients }\end{array}$ & + & 100 & $23 / 23$ & $9(6-9)$ \\
\hline 22 & $\begin{array}{l}\text { Screening for dumping syndrome in children is required especially in children with } \\
\text { microgastria, or when pyloroplasty or antireflux surgery has been performed }\end{array}$ & + & 95.7 & $22 / 23$ & $9(5-9)$ \\
\hline 23 & $\begin{array}{l}\text { When endoscopy is performed, there should be awareness of eosinophilic } \\
\text { esophagitis, and biopsies should be taken according to ESPGHAN guidelines }\end{array}$ & + & 100 & $22 / 22$ & $9(6-9)$ \\
\hline
\end{tabular}

Abbreviations: ERNICA, European Reference Network for Rare Inherited Congenital Anomalies; ESPGHAN, European Society for Pediatric Gastroenterology Hepatology and Nutrition; Gl, gastrointestinal.

${ }^{a}$ This item has already been discussed during the first ERNICA consensus conference on the management of patient with esophageal atresia with tracheoesophageal fistula.

${ }^{\mathrm{b}}$ This item has already been discussed during the first ERNICA consensus conference on the management of patient with esophageal atresia with tracheoesophageal fistula, but consensus could not be reached on this item.

\section{Table 7 Framework}

\begin{tabular}{|c|c|c|c|c|c|}
\hline & Statement & Consensus & $\%$ & Votes & $\begin{array}{l}\text { Median } \\
\text { (range) }\end{array}$ \\
\hline 1 & $\begin{array}{l}\text { When the diagnosis of long-gap esophageal atresia is confirmed, the patient } \\
\text { should be referred to a center of expertise in esophageal reconstructive surgery }\end{array}$ & + & 100 & $23 / 23$ & $9(7-9)$ \\
\hline 2 & $\begin{array}{l}\text { Long-gap esophageal atresia should be managed in centers with expertise in } \\
\text { esophageal reconstructive surgery, preferably with more than two cases per year }\end{array}$ & + & 91.3 & $21 / 23$ & $9(1-9)$ \\
\hline 3 & $\begin{array}{l}\text { When long-gap esophageal atresia is suspected, referral to antenatal multidisci- } \\
\text { plinary counseling in a center of expertise should be made }\end{array}$ & + & 95.7 & $22 / 23$ & $9(4-9)$ \\
\hline $4^{a}$ & $\begin{array}{l}\text { Parents of esophageal atresia patients should be informed about, and encouraged } \\
\text { to contact parent and patient support groups as early as possible }\end{array}$ & + & 100 & $23 / 23$ & $9(6-9)$ \\
\hline
\end{tabular}

Abbreviation: ERNICA, European Reference Network for Rare Inherited Congenital Anomalies.

${ }^{\mathrm{a}}$ This item has already been discussed during the first ERNICA consensus conference on the management of patient with esophageal atresia with tracheoesophageal fistula. 
Table 8 Consensus amongst participants of the second ERNICA consensus conference

\begin{tabular}{|l|l|}
\hline Consensus & No. of items (\%) \\
\hline $100 \%$ & $56(58)$ \\
\hline$>75 \%{ }^{\mathrm{a}}$ & $90(93)$ \\
\hline$<75 \%$ & $7(7)$ \\
\hline
\end{tabular}

Abbreviation: ERNICA, European Reference Network for Rare Inherited Congenital Anomalies.

${ }^{a}$ Votes that scored $6,7,8$, or 9 also including items that reached $100 \%$.

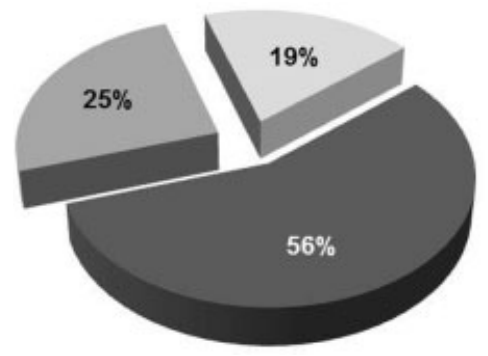

- Gastric transposition $=$ Jejunal interposition Colonic interposition

$n=16$ votes

Fig. 1 Preferred option of esophageal replacement.

latter statements, though they did not reach consensus (-Table 2). In addition, there was agreement that "long gap" is not an appropriate term to define the condition of long-gap esophageal atresia in its entirety. The term "wide-gap" esophageal atresia, which is used in some countries to identify cases where the anastomosis cannot be achieved despite the presence of a fistula, was proposed to be introduced as an adequate definition. However, participants decided not to vote on this new definition to avoid more confusion as long-gap esophageal atresia is a well-established and accepted term.

\section{Esophageal Reconstruction}

It had been suggested to vote on the surgical option of a gastric tube for esophageal reconstruction. After extensive discussion, it was decided not to vote on this item due to limited evidence in the literature 21,22 and lack of personal experience within the group.

\section{Postoperative Management}

An attempt was made to formulate a statement on the commencement of oral feeding. However, most participants felt that a definition of a specific time point would not be appropriate as individual parameters, such as duration of ventilator dependency, have a decisive impact on the postoperative time management. Therefore, no statement was formulated on the commencement of oral feeding.

\section{Follow-up}

Complete consensus was reached on the management of anastomotic strictures with balloon or semirigid dilatation (-Table 6). In this context, participants discussed the indication of peri-interventional antibiotic prophylaxis. Even if most of the participants supported peri-interventional antibiotic prophylaxis, the evidence in the available literature was considered to be too low allowing a meaningful vote.
Participants voted on treatment options for recurrent anastomotic strictures, such as topical application of mitomycin C, intralesional steroids, and stents (-Table 6). Participants also considered whether to vote on the application of indwelling balloon dilatation or endoscopic knife for recurrent anastomotic strictures. Moreover, surgical resection and esophageal reanastomosis was proposed as viable option in cases of failed treatment. Nonetheless, evidence for each of these options is scarce, ${ }^{23-25}$ and therefore, it was decided to abstain from formulating items for voting.

Complete consensus was reached on the statement that antacid therapy should be tapered at the end of prophylaxis (-Table 6). However, it was not possible to formulate a concrete instruction of how to taper the antacid medication due to a lack of evidence in literature and multiple suggestions by the participants.

\section{Need for Further Research}

The items on which either no consensus was reached or it was felt that there was insufficient evidence were suggested to be priorities for future research. - Table 9 summarizes relevant topics which urgently need further studies.

\section{Discussion}

The management of long-gap esophageal atresia remains challenging with limited evidence and consensus on the definition, evaluation, and surgical approach. ${ }^{2-4,9,26-28}$ The variety of management strategies that have been employed testify to the challenge it presents. ${ }^{8}$

In 2017, the International Network of Esophageal Atresia (INoEA) presented a position paper on the definition of longgap esophageal atresia and the best diagnostic and treatment strategies also highlighting the necessity of experience and communication in the management of these challenging patients. ${ }^{5}$ Recently, the American Pediatric Surgery Association (APSA) released a systematic review and 18 evidencebased guidelines, primarily based on levels 4 and 5 evidence, on the management of long-gap esophageal atresia. ${ }^{3}$

We hereby present the results of the second ERNICA consensus conference focusing on the perioperative, surgical, and long-term management of patients with long-gap esophageal atresia. In line with the first ERNICA consensus conference, ${ }^{14,15}$ this conference was based on two keystones: (1) on evidence from literature and (2) on expert opinion.

Participants of this conference achieved general consensus (defined by $\geq 75 \%$ of votes scoring 6-9) in $93 \%$ of all items ( $n=97$ ) which indicates a considerable level of agreement and suggests predominantly homogeneous approaches in ERNICA institutions. This is supported by the high rate of total agreement (defined as $100 \%$ consensus among voters) of $58 \%$ of all items. A maximum range of voting from 1 to 9 , indicating widely diverse opinions, was evident for only $20 \%$ of items which is low considering the huge variability of current treatment strategies.

Consensus was not reached in only $7 / 97$ votes (7\%), and all of these statements were discussed controversially (range 1-9; except one with a range 2-9): 
Table 9 Priorities for further research

\begin{tabular}{|c|c|c|}
\hline & Domain & Topic \\
\hline 1 & Diagnostics & Optimal approach for gap measurement \\
\hline 2 & Definitions & Comprehensive definition of "long-gap esophageal atresia" \\
\hline 3 & $\begin{array}{l}\text { Esophageal reconstruction } \\
\text { - Initial management } \\
\text { before reconstruction }\end{array}$ & Counseling of parents (ideally including the involvement of patient support groups) \\
\hline 4 & $\begin{array}{l}\text { Esophageal reconstruction } \\
\text { - Delayed primary anastomosis }\end{array}$ & Evidence for routine insertion of a transanastomotic tube \\
\hline 5 & $\begin{array}{l}\text { Esophageal reconstruction } \\
\text { - Delayed primary anastomosis }\end{array}$ & Evidence for routine placement of a chest drain \\
\hline 6 & $\begin{array}{l}\text { Esophageal reconstruction } \\
\text { - Lengthening techniques }\end{array}$ & Early and long-term outcome of different esophageal lengthening techniques \\
\hline 7 & Esophageal replacement & Evidence for optimal surgical technique for esophageal replacement \\
\hline 8 & $\begin{array}{l}\text { Esophageal replacement } \\
\text { - Gastric transposition }\end{array}$ & $\begin{array}{l}\text { Early and long-term outcome after gastric tube formation as an option } \\
\text { for esophageal replacement }\end{array}$ \\
\hline 9 & $\begin{array}{l}\text { Esophageal replacement } \\
\text { - Gastric transposition }\end{array}$ & Evidence for insertion of a transanastomotic tube during gastric transposition \\
\hline 10 & $\begin{array}{l}\text { Esophageal replacement } \\
\text { - Gastric transposition }\end{array}$ & Relevance of pyloroplasty (Mikulicz) during gastric transposition \\
\hline 11 & Postoperative management & $\begin{array}{l}\text { Evidence for routine postoperative contrast study of the esophagus before } \\
\text { initiation of oral feeding }\end{array}$ \\
\hline 12 & Postoperative management & Timing of the initiation of oral feeding \\
\hline 13 & Follow-up & Duration of postoperative antacid therapy \\
\hline 14 & Follow-up & Mode of tapering the postoperative antacid therapy \\
\hline 15 & Follow-up & $\begin{array}{l}\text { Evidence for peri-interventional antibiotic prophylaxis in balloon or semirigid } \\
\text { dilatation for anastomotic stricture }\end{array}$ \\
\hline 16 & Follow-up & $\begin{array}{l}\text { Application of indwelling balloon dilatation, endoscopic knife, and surgical } \\
\text { resection and reanastomosis in cases of recurrent anastomotic stricture }\end{array}$ \\
\hline
\end{tabular}

\section{Gap Measurement}

Accurate measurement of gap length is critical for operative planning for long-gap esophageal atresia. ${ }^{29,30}$ It is still a matter of debate whether preoperative contrast study to evaluate the upper esophageal pouch is needed. McDuffie et al stressed the high risk of aspiration ${ }^{31}$ which can be disastrous, as exemplified in a case-reported death of an infant. ${ }^{32}$ Moreover, Gross et al postulated that gap measurement with contrast media is not reliable as the lower pouch might be underestimated in the absence of reflux. ${ }^{29}$ Based on these arguments, the need for contrast studies for diagnostics has been essentially eliminated, ${ }^{33}$ and hence, gap measurement by contrast study of the upper and lower pouches was not considered to be a viable option by the participants of the conference.

\section{Definition of “Long-Gap” Esophageal Atresia}

Efforts have been made to define long-gap esophageal atresia as precisely as possible and not to accept subjective terms such as "inability to achieve primary end-to-end anastomosis." 3,4,6,9,34-36 However, there is no universally accepted methodology for determining either the gap length or what constitutes long-gap esophageal atresia. ${ }^{3}$ The APSA Committee-based on its members' opinion-stated that the nomenclature "Long Gap Esophageal Atresia" should not be reserved for Gross type A atresia exclusively, which is in line with the results of the participants' votes. The INoEA working group recently reaffirmed the unclear definition and suggested to define any esophageal atresia that has no intra-abdominal air should be considered a long gap. ${ }^{5}$

This statement reached complete consensus by all participants. However, it was additionally stated that this definition should not confine long-gap esophageal atresia to pure atresia (Gross type A or B), but should allow inclusion of esophageal atresia with tracheoesophageal fistula with a wide gap, respectively, with different anatomic configurations. ${ }^{1,36-39}$ Participants decided not to vote on this proposed term of "wide gap" to avoid more confusion. As a result of a highly controversial discussion on the definition of long-gap esophageal atresia, consensus was reached on important statements. It must be emphasized, however, that the condition of long-gap esophageal atresia is not fully depicted yet by these definitions.

\section{Esophageal Reconstruction}

There is no consensus on the preferred method of esophageal reconstruction to date..$^{2,4,8,26,40-42}$ No randomized controlled trials comparing different approaches of surgical repair or comparing the various techniques used to manage long-gap esophageal atresia are available. ${ }^{8}$ Fundamentally, it must be 
stated that preservation of the native esophagus should be aimed before considering any replacement technique $9,28,43$ as "no other conduit can replace its function in transporting food from the oral cavity to the stomach satisfactorily". ${ }^{44}$ In this light, it is interesting to mention that thoracoscopic pouch mobilization and placement of traction sutures are considered a novel technique that shows promise, but should only be performed in specialized centers with prospective review and reporting of outcomes ( - Table $3, \mathrm{f}$ ).

Various different techniques deal with esophageal replacement, reflecting that none has been suggested to be ideal, and the patients are left with many challenges to overcome. ${ }^{2,9,43,45,46}$ In this context, participants voted on the preferred option for esophageal replacement ( - Fig. 1). The majority of participants voted for gastric transposition (56\%), followed by jejunal interposition (25\%) and finally followed by colonic interposition (19\%). The voting result corresponds to the current literature as multiple studies confirmed that the stomach is the preferred organ for esophageal replacement. ${ }^{8,47-50}$ In addition, the high rate of abstention from voting $(30 \%)$ indicates the disagreement of preferred surgical options. The latest systematic review of the surgical treatment of long-gap esophageal atresia by Stadil et al aimed to compare the postoperative complications related to the different methods within the first postoperative year. ${ }^{40}$ Fifty-seven articles were included involving 326 patients with Gross types A and B long-gap esophageal atresia. ${ }^{40}$ Delayed primary anastomosis was the most applied surgical method (68.4\%) in both types, followed by gastric transposition (8.3\%) which is in line with the statements achieved during the consensus conference.

Literature provides some evidence for colonic interposition to be a surgical option comparable to other replacement techniques. ${ }^{2,51,52}$ Nonetheless, the INoEA working group stated that colonic interposition is mainly reserved as a last option, when all other techniques have failed or are considered unfeasible. ${ }^{5}$ After extensive discussion, participants of this conference did not reach consensus on colonic interposition as a viable option for esophageal replacement mainly driven by evidence from literature $e^{5,53-55}$ and individual experience.

\section{Placement of Chest Drain}

Routine placement of a chest drain in delayed primary anastomosis was also controversially discussed. Several studies postulated that a chest drain does not alter early postoperative complications after repair of esophageal atresia with tracheoesophageal fistula. ${ }^{56-58}$ Participants generally agreed that the placement of a chest drain for delayed primary anastomosis has to be valued differently compared with primary repair due to higher risk of anastomotic leakage based on an anastomosis under tension. Even though a clear majority of voters supported the routine placement of a chest drain, consensus was not reached on this item.

\section{Postoperative Contrast Study}

Evidence on "routine postoperative contrast study of the esophagus before the initiation of oral feeding" is scarce. ${ }^{59,60}$ Yanchar et al presented a study including 90 patients who underwent esophageal atresia repair and postoperative upper gastrointestinal contrast study before consideration of oral feeding. ${ }^{60}$ They concluded that the use of early routine contrast studies, with no suspicion of a problem, has little value in terms of predicting complications or future clinical course. ${ }^{60}$ These findings support the participants' votes not advocating for a routine postoperative contrast study in the absence of any clinical findings.

Given the complexity of this patient population with significant morbidity and associated anomalies, treatment and long-term follow-up should be managed by specialized and multidisciplinary teams. ${ }^{9,11,28,61}$ There are growing demands for referral of esophageal atresia patients to designated centers of expertise just as it is common practice in the Netherlands or in France, and these demands are even stronger for patients with long gap.,4,8,9,14,15,62,63 These repeatedly expressed requirements to fulfill the criteria of optimal patient care are reflected in the consensus statements in the domain Framework.

Although the consensus meeting was focused entirely on long-gap congenital esophageal atresia, esophageal reconstruction is also often necessary for children with caustic injury, button battery ingestion, or other acquired/iatrogenic esophageal damage. Although the statements generated are not directly applicable to such children, some of the statements might be considered as relevant and useful in the absence of any specific consensus guidelines on treatment of children with acquired esophageal damage.

As stated previously, the strength of this conference is the pool of participating specialists with extensive expertise in this field. ${ }^{14,15}$ The multidisciplinary approach was highly valued in the first ERNICA consensus conference allowing discussion from various perspectives. Considering this beneficial methodological approach, the group of participants had been extended to representatives of the specialty neonatology and pediatric pulmonology. Further advantages, such as the methodology (characterized by meticulous item generation and prioritization, systematic literature search, and anonymous voting), ability to modify wording of statements via the online voting system, abstention from voting in case of lacking expertise, and involvement of representatives of the patient support groups ensure the high quality of results and indicate the great validity of votes.

Nonetheless, it has to be emphasized that the results of the conference were mainly based on expert opinion, and not on evidence. $^{14,15}$

\section{Conclusion}

Evidence supporting best practices for long-gap esophageal atresia is weak. We hereby present consensus statements on the perioperative, surgical, and long-term management of patients with long-gap esophageal atresia based on a critical evaluation of the current literature. Areas of controversy were identified for future research. Substantial statements regarding esophageal reconstruction or replacement and follow-up were formulated which may contribute to optimized and uniform patient care. 


\author{
Funding \\ ERNICA provided financial support for the conference.
}

\section{Conflict of Interest}

None declared.

\section{Acknowledgments}

S.E., K.M.C., and P.D.C. gratefully acknowledge the support of the National Institute for Health Research Great Ormond Street Hospital Biomedical Research Centre. The views expressed are those of the authors and not necessarily those of the NHS, the NIHR, or the UK Department of Health.

\section{References}

1 Bagolan P, Valfrè L, Morini F, Conforti A. Long-gap esophageal atresia: traction-growth and anastomosis - before and beyond. Dis Esophagus 2013;26(04):372-379

2 Gallo G, Zwaveling S, Groen H, Van der Zee D, Hulscher J. Long-gap esophageal atresia: a meta-analysis of jejunal interposition, colon interposition, and gastric pull-up. Eur J Pediatr Surg 2012;22(06): 420-425

3 Baird R, Lal DR, Ricca RL, et al. Management of long gap esophageal atresia: a systematic review and evidence-based guidelines from the APSA Outcomes and Evidence Based Practice Committee. J Pediatr Surg 2019;54(04):675-687

4 von Allmen D, Wijnen RM. Bridging the gap in the repair of longgap esophageal atresia: still questions on diagnostics and treatment. Eur J Pediatr Surg 2015;25(04):312-317

5 van der Zee DC, Bagolan P, Faure C, et al. Position paper of INoEA working group on long-gap esophageal atresia: for better care. Front Pediatr 2017;5:63

6 Spitz L. Esophageal atresia. Lessons I have learned in a 40-year experience. J Pediatr Surg 2006;41(10):1635-1640

7 Zani A, Eaton S, Hoellwarth ME, et al. International survey on the management of esophageal atresia. Eur J Pediatr Surg 2014;24 (01):3-8

8 Ron O, De Coppi P, Pierro A. The surgical approach to esophageal atresia repair and the management of long-gap atresia: results of a survey. Semin Pediatr Surg 2009;18(01):44-49

9 European Reference Networks. Available at: https://ern-ernica.eu/ about/european-reference-networks/. Accessed February 10, 2020

10 Wijnen R, Anzelewicz SM, Petersen C, Czauderna P. European Reference Networks: share, care, and cure-future or dream? Eur J Pediatr Surg 2017;27(05):388-394

11 Rolle U. Centralization of pediatric surgery: European perspective. Eur J Pediatr Surg 2017;27(05):387

12 Pakarinen M, Bjørland K, Qvist N, Wester T. Centralized pediatric surgery in the Nordic countries: a role model for Europe? Eur J Pediatr Surg 2017;27(05):395-398

13 Héon-Klin V. European Reference Networks for rare diseases: what is the conceptual framework? Orphanet J Rare Dis 2017;12 (01):137

14 Dingemann C, Eaton S, Aksnes G, et al. ERNICA consensus conference on the management of patients with esophageal atresia and tracheoesophageal fistula: diagnostics, preoperative, operative, and postoperative management. Eur J Pediatr Surg 2019. Doi: 10.1055/s-0039-1693116

15 Dingemann C, Eaton S, Aksnes G, et al. ERNICA consensus conference on the management of patients with esophageal atresia and tracheoesophageal fistula: follow-up and framework. Eur J Pediatr Surg 2019. Doi: 10.1055/s-0039-3400284

16 Available at: http://www.we-are-eat.org/. Accessed February 10, 2020

17 Oxford Centre for Evidence-based Medicine - Levels of Evidence. (March 2009). Available at: https://www.cebm.net/2009/06/ox- ford-centre-evidence-based-medicine-levels-evidence-march2009/. Accessed June 23, 2019

18 Harris PA, Taylor R, Thielke R, Payne J, Gonzalez N, Conde JG. Research Electronic Data Capture (REDCap)-a metadata-driven methodology and workflow process for providing translational research informatics support. J Biomed Inform 2009;42(02):377-381

19 Available at: www.voxvote.com. Accessed February 10, 2020

20 Krishnan U, Mousa H, Dall'Oglio L, et al. ESPGHAN-NASPGHAN guidelines for the evaluation and treatment of gastrointestinal and nutritional complications in children with esophageal atresia-tracheoesophageal fistula. J Pediatr Gastroenterol Nutr 2016; 63(05):550-570

21 Elfiky MM, El Tagy G, Mohamed W, Abdel Azim O, Elfiky MA. Gastric tube esophagoplasty for pediatric esophageal replacement. J Pediatr Surg 2017;52(04):657-662

22 Choudhury SR, Yadav PS, Khan NA, et al. Pediatric esophageal substitution by gastric pull-up and gastric tube. J Indian Assoc Pediatr Surg 2016;21(03):110-114

23 van der Zee D, Hulsker C. Indwelling esophageal balloon catheter for benign esophageal stenosis in infants and children. Surg Endosc 2014;28(04):1126-1130

24 Samanta J, Dhaka N, Sinha SK, Kochhar R. Endoscopic incisional therapy for benign esophageal strictures: technique and results. World J Gastrointest Endosc 2015;7(19):1318-1326

25 Tambucci R, Angelino G, De Angelis P, et al. Anastomotic strictures after esophageal atresia repair: incidence, investigations, and management, including treatment of refractory and recurrent strictures. Front Pediatr 2017;5:120

26 Bruns NE, Glenn IC, Ponsky TA. Esophageal atresia: state of the art in translating experimental research to the bedside. Eur J Pediatr Surg 2019;29(04):328-335

27 van Lennep M, Singendonk MMJ, Dall'Oglio L, et al. Oesophageal atresia. Nat Rev Dis Primers 2019;5(01):26

28 Shieh HF, Jennings RW. Long-gap esophageal atresia. Semin Pediatr Surg 2017;26(02):72-77

29 Gross ER, Reichstein A, Gander JW, Stolar CJ, Coran AG, Cowles RA The role of fiberoptic endoscopy in the evaluation and management of long gap isolated esophageal atresia. Pediatr Surg Int 2010;26(12):1223-1227

30 Upadhyaya VD, Gangopadhyaya AN, Gupta DK, et al. Prognosis of congenital tracheoesophageal fistula with esophageal atresia on the basis of gap length. Pediatr Surg Int 2007;23(08): 767-771

31 McDuffie LA, Wakeman D, Warner BW. Diagnosis of esophageal atresia with tracheoesophageal fistula: is there a need for gastrointestinal contrast? J Pediatr 2010;156(05):852

32 McAlister $\mathrm{WH}$, Siegel MJ. Fatal aspirations in infancy during gastrointestinal series. Pediatr Radiol 1984;14(02):81-83

33 Atzori P, Iacobelli BD, Bottero S, et al. Preoperative tracheobronchoscopy in newborns with esophageal atresia: does it matter? J Pediatr Surg 2006;41(06):1054-1057

34 Parilli A, García W, Mejías JG, Galdón I, Contreras G. Laparoscopic transhiatal esophagectomy and gastric pull-up in long-gap esophageal atresia: description of the technique in our first 10 cases. J Laparoendosc Adv Surg Tech A 2013;23(11):949-954

35 Al-Shanafey S, Harvey J. Long gap esophageal atresia: an Australian experience. J Pediatr Surg 2008;43(04):597-601

36 Koivusalo A, Suominen J, Rintala R, Pakarinen M. Location of TEF at the carina as an indicator of long-gap C-type esophageal atresia. Dis Esophagus 2018;31(11):

37 Thakkar HS, Cooney J, Kumar N, Kiely E. Measured gap length and outcomes in oesophageal atresia. J Pediatr Surg 2014;49(09): 1343-1346

38 Castilloux J, Noble AJ, Faure C. Risk factors for short- and longterm morbidity in children with esophageal atresia. J Pediatr 2010;156(05):755-760

39 Jönsson L, Friberg LG, Gatzinsky V, Kötz K, Sillén U, Abrahamsson K. Treatment and follow-up of patients with long-gap esophageal 
atresia: 15 years' of experience from the western region of Sweden. Eur J Pediatr Surg 2016;26(02):150-159

40 Stadil T, Koivusalo A, Svensson JF, et al. Surgical treatment and major complications within the first year of life in newborns with long-gap esophageal atresia gross type A and B - a systematic review. J Pediatr Surg 2019;54(11):2242-2249

41 Long AM, Tyraskis A, Allin B, Burge DM, Knight M. Oesophageal atresia with no distal tracheoesophageal fistula: management and outcomes from a population-based cohort. J Pediatr Surg 2017;52(02):226-230

42 Friedmacher F, Puri P. Delayed primary anastomosis for management of long-gap esophageal atresia: a meta-analysis of complications and long-term outcome. Pediatr Surg Int 2012;28(09): 899-906

43 Zani A, Cobellis G, Wolinska J, Chiu PP, Pierro A. Preservation of native esophagus in infants with pure esophageal atresia has good long-term outcomes despite significant postoperative morbidity. Pediatr Surg Int 2016;32(02):113-117

44 Myers NA. Oesophageal Atresia: The Epitome of Modern Surgery. Ann R Coll Surg Engl. 1974 Jun;54(06):277-287

45 Bairdain S, Hamilton TE, Smithers CJ, et al. Foker process for the correction of long gap esophageal atresia: Primary treatment versus secondary treatment after prior esophageal surgery. J Pediatr Surg 2015;50(06):933-937

46 van der Zee DC, Gallo G, Tytgat SH. Thoracoscopic traction technique in long gap esophageal atresia: entering a new era. Surg Endosc 2015;29(11):3324-3330

47 Garritano S, Irino T, Scandavini CM, Tsekrekos A, Lundell L, Rouvelas I. Long-term functional outcomes after replacement of the esophagus in pediatric patients: a systematic literature review. J Pediatr Surg 2017;52(09):1398-1408

48 Foster JD, Hall NJ, Keys SC, Burge DM. Esophageal replacement by gastric transposition: a single surgeon's experience from a tertiary pediatric surgical center. J Pediatr Surg 2018;53(11): 2331-2335

49 Stadil T, Koivusalo A, Pakarinen M, et al. Surgical repair of longgap esophageal atresia: a retrospective study comparing the management of long-gap esophageal atresia in the Nordic countries. J Pediatr Surg 2019;54(03):423-428

50 Loukogeorgakis SP, Pierro A. Replacement surgery for esophageal atresia. Eur J Pediatr Surg 2013;23(03):182-190

51 Burgos L, Barrena S, Andrés AM, et al. Colonic interposition for esophageal replacement in children remains a good choice: 33-year median follow-up of 65 patients. J Pediatr Surg 2010;45 (02):341-345

52 Liu J, Yang Y, Zheng C, Dong R, Zheng S. Surgical outcomes of different approaches to esophageal replacement in long-gap esophageal atresia: a systematic review. Medicine (Baltimore) 2017;96(21):e6942

53 Coopman S, Michaud L, Halna-Tamine M, et al. Long-term outcome of colon interposition after esophagectomy in children. J Pediatr Gastroenterol Nutr 2008;47(04):458-462

54 Dhir R, Sutcliffe RP, Rohatgi A, Forshaw MJ, Strauss DC, Mason RC. Surgical management of late complications after colonic interposition for esophageal atresia. Ann Thorac Surg 2008;86(06): 1965-1967

55 Baggaley A, Reid T, Davidson J, de Coppi P, Botha A. Late life revision surgery for dilated colonic conduit in long gap oesophageal atresia. Ann R Coll Surg Engl 2018;100(07):e185-e187

56 Gawad N, Wayne C, Bass J, Nasr A. A chest tube may not be needed after surgical repair of esophageal atresia and tracheoesophageal fistula. Pediatr Surg Int 2018;34(09):967-970

57 Paramalingam S, Burge DM, Stanton MP. Operative intercostal chest drain is not required following extrapleural or transpleural esophageal atresia repair. Eur J Pediatr Surg 2013;23(04): 273-275

58 Aslanabadi S, Jamshidi M, Tubbs RS, Shoja MM. The role of prophylactic chest drainage in the operative management of esophageal atresia with tracheoesophageal fistula. Pediatr Surg Int 2009;25(04):365-368

59 Sodhi KS, Saxena AK, Ahuja CK, Rao K, Menon P, Kandelwal N. Postoperative appearances of esophageal atresia repair: retrospective study of 210 patients with review of literature - what the radiologist should know. Acta Radiol 2013;54(02):221-225

60 Yanchar NL, Gordon R, Cooper M, Dunlap H, Soucy P. Significance of the clinical course and early upper gastrointestinal studies in predicting complications associated with repair of esophageal atresia. J Pediatr Surg 2001;36(05):815-822

61 Langer JC, Gordon JS, Chen LE. Subspecialization within pediatric surgical groups in North America. J Pediatr Surg 2016;51(01): 143-148

62 Sfeir R, Michaud L, Sharma D, Richard F, Gottrand F. National esophageal atresia register. Eur J Pediatr Surg 2015;25(06): 497-499

63 Ure B. Esophageal atresia, Europe, and the future: BAPS Journal of Pediatric Surgery Lecture. J Pediatr Surg 2019;54(02):217-222 